\title{
HUBUNGAN TEKNOLOGI INFORMASI DAN FORMULASI STRATEGI KOMPETITIF SERTA DAMPAKNYA TERHADAP KINERJA ORGANISASIONAL: KERANGKA KONSEPTUAL
}

\author{
Agustinus Dedy Handrimurtjahjo \\ Jurusan Manajemen, School of Business Management, Universitas Bina Nusantara \\ Jln. K.H. Syahdan No. 9, Palmerah, Jakarta Barat 11480 \\ ahandrimurtjahjo@binus.edu
}

\begin{abstract}
The relationship between IT and firm performance is a crucial research issue that symbolizes the value of information systems research. Many studies have attempted to understand the role of IT in organizational performance, and more researchers are paying attention to the notion of IT capabilities, including their potential to transform IT resources into business value. Meanwhile, the other study identified and investigated the three building blocks of IT deployment capabilities: strategic IT flexibility, business-IT partnership, and business-IT alignment. Using the resource-based view, the study propose a framework to explain the relationship between IT deployment capabilities and competitive advantage. This paper aims to find relationship between IT and Competitive Strategies and their impact on Organizational Performance.
\end{abstract}

Keywords: information technology, competitive strategic, organizational performance

\begin{abstract}
ABSTRAK
Hubungan antara TI dan kinerja perusahaan adalah masalah penelitian penting yang melambangkan nilai penelitian sistem informasi. Banyak penelitian telah berusaha untuk memahami peran TI dalam kinerja organisasi, dan banyak peneliti yang memperhatikan peran kemampuan TI, termasuk potensi mereka untuk mengubah sumber daya TI ke dalam nilai bisnis. Sementara itu, studi lain mengidentifikasi dan menginvestigasi tiga blok bangunan kapabilitas penyebaran TI: Strategic IT flexibility, business-IT partnership, and business-IT alignment. Menggunakan tampilan berbasis sumber daya, penelitian ini mengemukakan kerangka kerja untuk menjelaskan hubungan antara kapabilitas penyebaran IT dengan keunggulan kompetitif. Makalah ini bertujuan untuk menemukan hubungan antara IT dan Strategi kompetitif serta dampaknya terhadap Kinerja Organisasi.
\end{abstract}

Kata kunci: information technology, competitive strategic, organizational performance 


\section{PENDAHULUAN}

Hubungan antara Teknologi Informasi (TI) dan kinerja perusahaan merupakan isu riset yang penting yang melambangkan nilai dari riset sistem informasi (Devaraj dan Kohli, 2003; Tanriverdi, 2005 dalam Kim et al., 2011). Banyak studi telah dilakukan untuk mencoba memahami peran TI dalam kinerja organisatoris. Peneliti lebih perhatian terhadap gagasan IT capabilities termasuk potensinya untuk mengubah sumber daya IT ke dalam nilai bisnis (Kim et al., 2011). Kontribusi TI untuk pencapaian tujuan bisnis juga merupakan isu manajemen penting (Rivard et al., 2006). Memang, survei tahunan Computer Sciences Corporation tahun 2001 melaporkan TI sebagai isu paling penting kedua untuk eksekutif IT Amerika Utara (CSC, 2001 dalam Rivard et al., 2005). TI juga telah menjadi isu yang abadi setiap tahun sejak survei edisi tahun 1991 dan telah menjadi ranking lima besar manajemen TI. Dalam hubungannya dengan riset, berbagai studi mengadopsi berbagai perspektif, telah memfokuskan pada masalah riset ini untuk beberapa tahun (Melville et al., 2004).

Rivard et al., (2006) melakukan studi untuk meningkatkan pemahaman kontribusi TI terhadap kinerja perusahaan dalam membangun hubungan saling melengkapi antara dua persperktif tersebut. Mereka melakukan studinya dengan model yang diusulkan oleh Spanos dan Lioukas (2001), menguji hubungan sebab akibat logika generasi aliran (rent generation) : membandingkan kerangka strategi kompetitif Porter dan perspektif berbasis sumber daya (resource-based). Sementara itu Huang dan $\mathrm{Hu}$ (2007) melakukan kajian studi kasus di mana empat elemen utama keterpaduan bisnis-TI (IT business alignment) : integrated planning, effective communication, active relationship management dan institutionalized culture of alignment - ditingkatkan melalui enterprise-wide implementation dari alat manajemen strategis yaitu balanced scorecard.

Studi yang dilakukan Tian et al. (2009) mengidentifikasi dan mengkaji tiga blok bangunan kapabilitas penyebaran TI (IT deployment capabilities): IT flexibility, business-IT partnership dan business-IT alignment. Dengan menggunakan pandangan berbasis sumber daya (resource-based view), mereka mengusulkan kerangka untuk menjelaskan hubungan antara kapabilitas penyebaran TI dan keunggulan kompetitif. Sedangkan Kim et al. (2011) melakukan studi dengan mengkaji dan menguji secara empirik pengaruh hubungan antara kapabilitas TI (IT personal expertise, IT infrastructure flexibility dan IT management capabilities), process-oriented dynamic capabilities dan kinerja keuangan.

Berdasarkan kajian beberapa peneliti diatas, penelitian ini bertujuan untuk menemukan hubungan Teknologi Informasi (TI) dan Strategi Kompetitif serta dampaknya terhadap Kinerja Organisatoris.

\section{METODE}

Untuk membahas topik yang dikaji dalam tulisan ini digunakan Metode Kajian Pustaka (Literature Review). Kajian Pustaka ini untuk memecahkan suatu masalah yang pada dasarnya bertumpu pada penelaahan yang kritis dan mendalam terhadap bahan-bahan pustaka yang relevan. Telaah pustaka dilakukan dengan cara mengumpulkan data atau informasi dari berbagai sumber pustaka yang diperlukan sebagai sumber ide untuk menggali pemikiran atau gagasan baru, sebagai bahan dasar untuk melakukan deduksi dari pengetahuan yang sudah ada, sehingga kerangka teori baru dapat dikembangkan, atau sebagai dasar pemecahan masalah. Pendekatan literature review, terdiri dari lima tahap yaitu terdiri dari : (1) Find models. (2) Problem formulation - which topic is under consideration and what are the constituent issues? (3) Literature search. (4) Evaluation of findings. (5) Analysis and interpretation of literature. 
Sumber-sumber pustaka yang dikaji dalam tulisan ini berupa : buku, hasil penelitian, jurnal dan artikel ilmiah lainnya. Langkah-langkah pembuatan literature review dijabarkan sebagai berikut: (a) Menetapkan sumber-sumber untuk bahan literature review yang sesuai dengan topik kajian tulisan ini (b) Mengevaluasi isi yang dimuat di dalam sumber-sumber studi pustaka yang ditetapkan. Pada bagian ini dapat dimuat hal-hal yang berkaitan dengan anggapan-anggapan dasar atau fakta-fakta yang dipandang benar tanpa ada verifikasi dan keterbatasan, yaitu aspek-aspek tertentu yang dijadikan kerangka berpikir. Analisis ini diperlukan untuk menyusun alur berpikir dalam memecahkan masalah (c) Membuat summary terhadap isi sumber-sumber studi pustaka. (d) Menggali pemikiran dan gagasan baru terhadap topik yang menjadi bahan kajian untuk menetapkan positioning konsep sebagai bahan penelitian berikutnya.

\section{Kajian Pustaka}

Dua perspektif riset yang berasal dari literatur manajemen strategik adalah perspektif yang menggambarkan kekuatan pasar dan pandangan berbasis sumber daya (resource-based view). Pada perspektif berbasis kekuatan pasar, dalam konteks TI, Porter dan Millar (1985) melihat TI sebagai cara di mana perusahaan dapat memperoleh keunggulan kompetitif dengan mengubah kekuatan kompetitif yang secara kolektif menentukan profitabilitas. TI dapat mengkontribusikan perubahan kekuatan kompetitif melalui kontribusi menurunkan biaya dan meningkatkan diferensiasi (Rivard et al., 2006). Pada perspektif berbasis sumber daya, dalam konteks TI, perspektif melihat sendiri kapabilitas TI (IT capabilities) : infrastruktur TI, sumber daya manusia TI dan IT intangibles - sebagai sumber keunggulan kompetitif (Bharadwaj dalam Rivard et al., 2006).

Hasil studi yang dilakukan oleh Rivard et al., (2006) dengan melakukan survei pada 96 perusahaan berukuran kecil-menengah antara lain sebagai berikut: (1) Terdapat hubungan yang signifikan antara IT support for strategy dan kekuatan industri; (2) Terdapat hubungan yang signifikan antara kekuatan industri dan kinerja; (3) Terdapat hubungan yang signifikan antara IT support for strategy dan performance; (4) Terdapat hubungan yang signifikan antara IT support for firms assets dan performance; (5) Terdapat hubungan yang signifikan antara IT support for firm assets dan IT support for strategy; (6) Adanya dampak IT support for strategy dan IT support for firm assets terhadap performance.

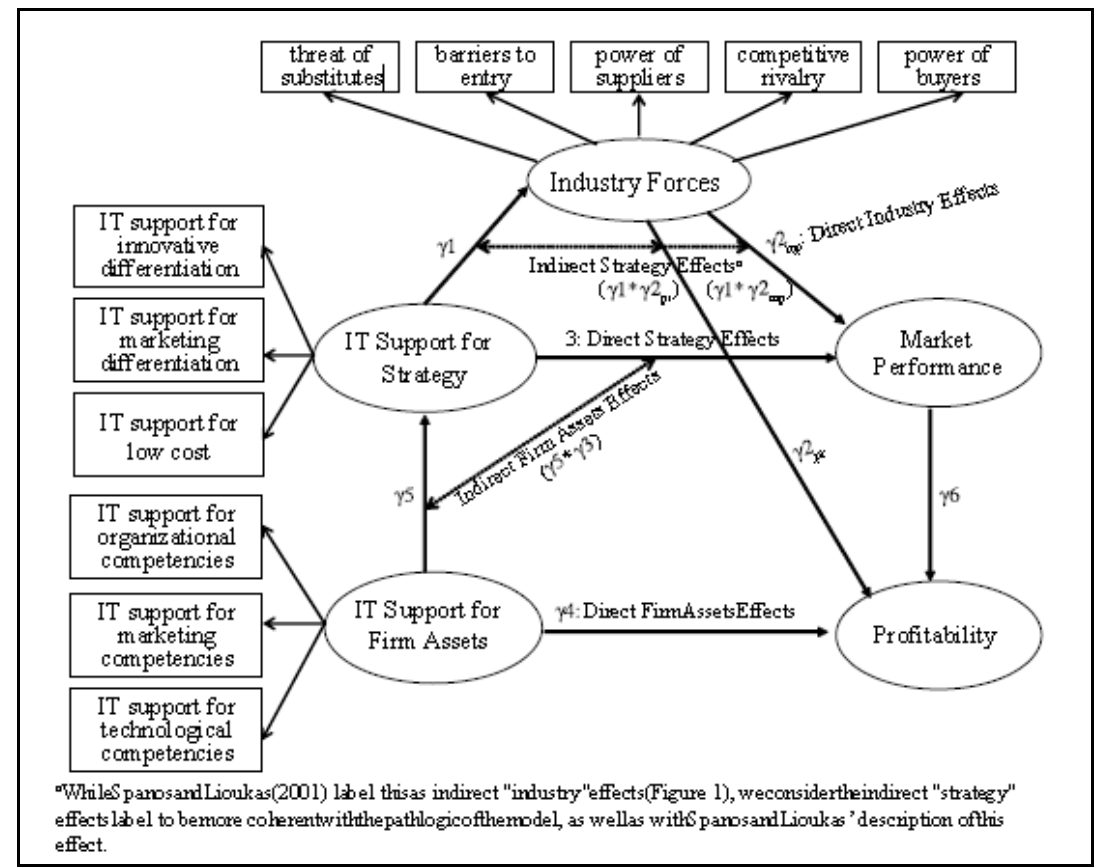

Gambar 1. Model Riset IT Support, Competitif Strategy dan Performance (Rivard et al., 2006) 
Dalam studinya, Huang dan Hu (2007) menyatakan bahwa pertama, TI tidak dapat berdiri sendiri untuk keterpaduan (alignment). Keterpaduan TI dan bisnis merupakan bagian keseluruhan program strategik perusahaan, dimana implementasi balanced scorecard merupakan alat yang tepat. Kedua, alignment merupakan proses bertahap dan kontinyu, bukan sesuatu yang terjadi dalam satu malam. Bahkan dengan intensi, perencanaan dan eksekusi, alignment dapat membentur halangan organisasional, kultural dan politik.

Hasil studi yang dilakukan Tian et al. (2009) menunjukkan bahwa strategic IT flexibility dan business-IT partnership memiliki dampak langsung pada keunggulan kompetitif, sementara businessIT alignment memiliki dampak tidak langsung pada keunggulan kompetitif. Dampak business-IT alignment pada keunggulan kompetitif dimediasi penuh oleh strategic IT flexibiliy dan business-IT partnership. Hasil memberikan dukungan bagi hubungan antara IT deployment capabilities dan keunggulan kompetitif.

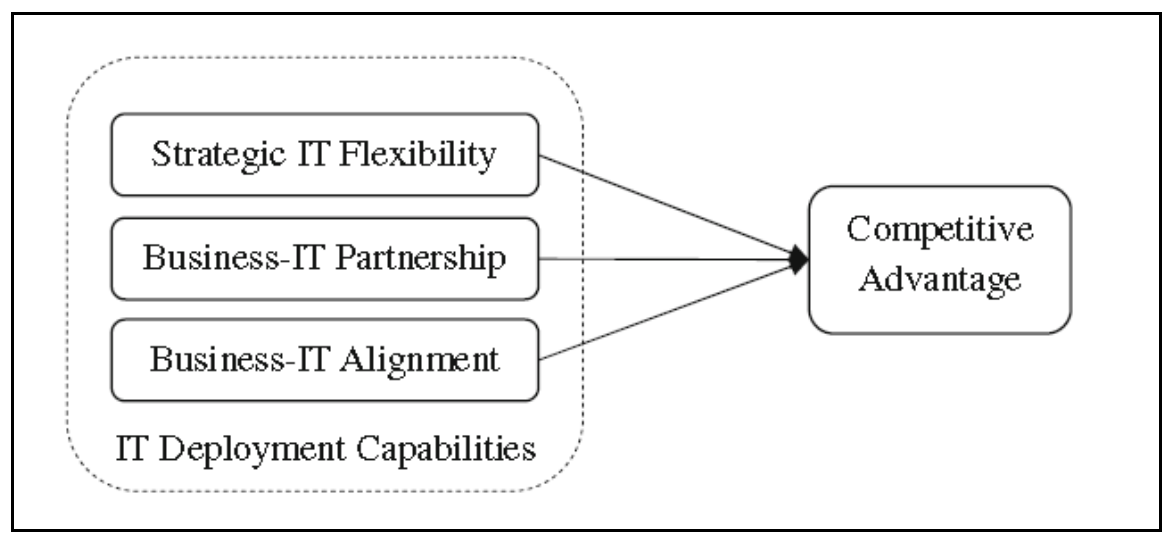

Gambar 2 Model Konsep IT Deployment Capabilities dan Competitive Advantage (Tian et al. (2009)

Kim et al., (2011) dalam studinya menemukan jalur kausalitas penting sebagai berikut : IT personnel expertise $\rightarrow$ IT management capabilities $\rightarrow$ IT infrastructure flexibility $\rightarrow$ process-oriented dynamic capabilities $\rightarrow$ financial performance. Studinya menguji hubungan antara IT capabilities, kemampuan membentuk proses bisnis dan ekonomi perusahaan yang sukses. Mereka juga menelusuri hubungan sebab akibat antara IT capabilities meliputi IT personnel expertise, IT management capabilities dan IT infrastructure flexibility. Secara keseluruhan, analisis menunjukkan bahwa IT capabilities berkontribusi secara tidak langsung terhadap kinerja keuangan yang dipersepsikan dari perusahaan dengan menambahkan process-oriented dynamic capabilities (PDC) yang dianggap penting dalam mempertahankan proses operasional yang efektif (atau membentuk kembali). Meskipun beberapa studi menyoroti arti penting sumber daya manusia (seperti keahlian TI) dan infrastruktur TI, studi tersebut memperjelas peran kapabilitas manajemen TI dalam menjembatani kesenjangan antara keduanya dan pada akhirnya memperkuat pencapaian kinerja keuangan perusahaan. 


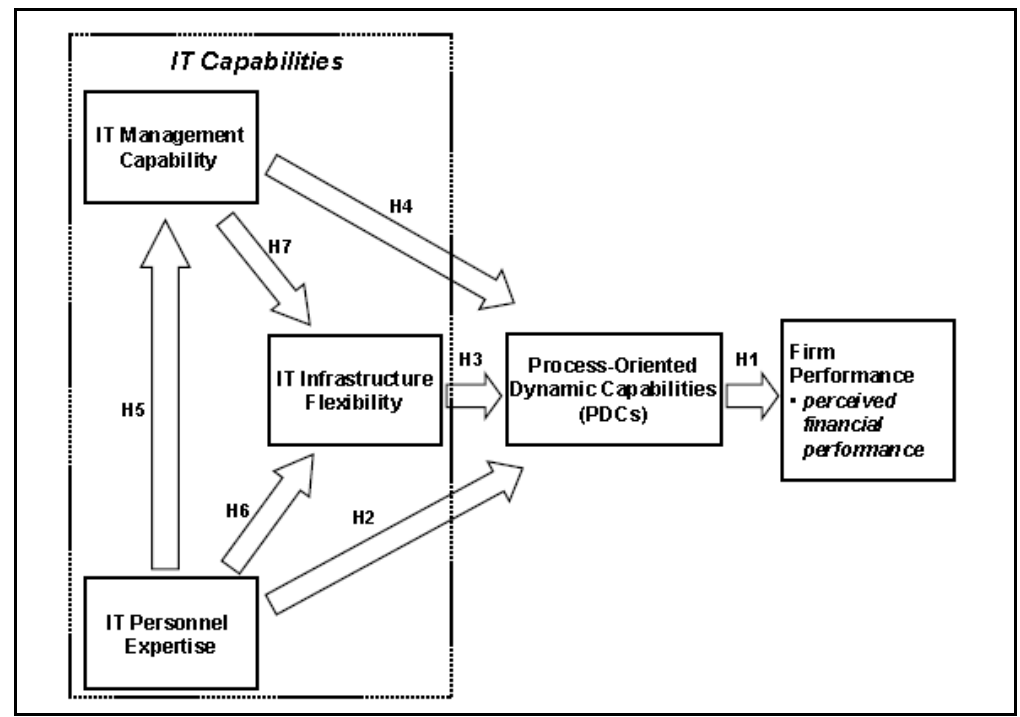

Gambar 3 Model Riset IT Capabilities, PDC dan Firm Performance (Kim et al., 2011)

Dari hasil studi diatas, penulis mengembangkan kerangka konseptual hubungan antara Teknologi Informasi dan Strategi Kompetitif serta dampaknya pada Kinerja Organisatoris seperti digambarkan dibawah ini :

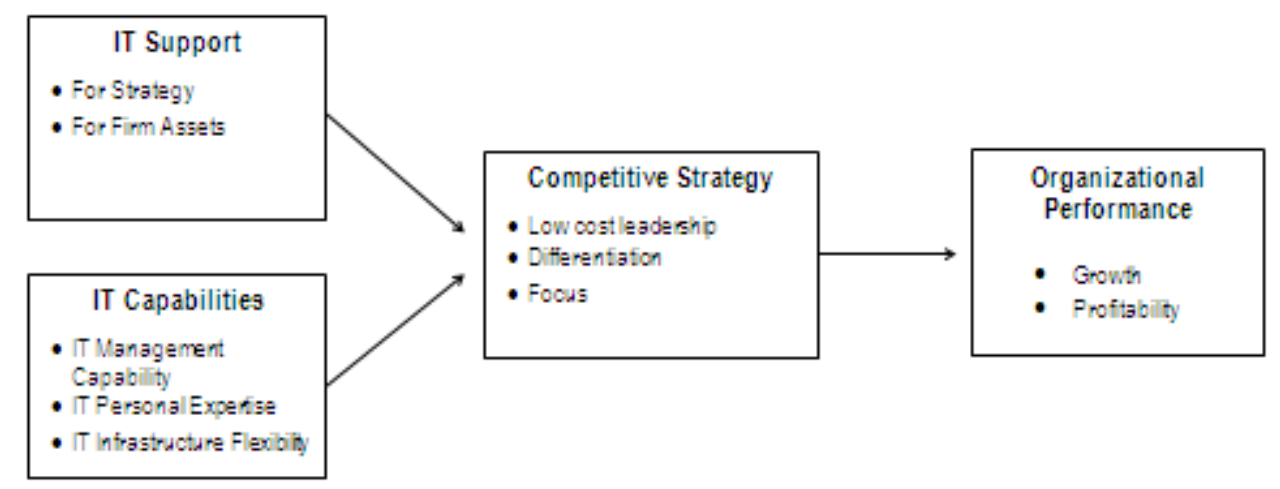

Gambar 4 Model Konseptual Information Technology, Competitive Strategy dan Organizational Performance

\section{HASIL DAN PEMBAHASAN}

\section{Deskripsi Variabel}

\section{Competitive Strategy (Market Driven Perspective)}

Kerangka strategi bersaing Porter $(1980,1991)$ mengidentifikasi lima kekuatan industri yaitu intensitas persaingan industri, ancaman pendatang baru, ancaman produk pengganti, kekuatan tawar menawar supplier dan kekuatan tawar menawar konsumen. Kekuatan ini menentukan profit potensial dari industri atau segmen industri (Teece et al., 1997). Dalam konteks itu, perusahaan harus mengidentifikasi kekuatan dan menentukan bagaimana menemukan posisi terbaik dalam industri sehingga dapat mempertahankan dirinya sendiri dalam persaingan (defensive effects) atau memanfaatkan pengaruh mereka (offensive effects) (Teece et al., 1997). Cara perusahaan memilih 
untuk meningkatkan posisi bersaing seharusnya menciptakan kesulitan yang signifikan bagi yang lain untuk meniru, sehingga menghasilkan keunggulan bersaing jangka panjang. Porter menempatkan bahwa posisi relatif menarik adalah hasil dari salah satu dari dua jenis keunggulan bersaing : lower cost dibandingkan pesaing atau kemampuan untuk membedakan (differentiate) dan mengendalikan harga premium lebih dari biaya ekstra diferensiasi. Dalam pandangan ini, profitabilitas unggul hanya dapat secara logis muncul dari perintah harga yang lebih tinggi dibandingkan pesaing atau menikmati biaya yang lebih rendah (Porter, 1991)

Sejumlah peneliti TI telah mengadopsi perspektif market driven untuk menguji dampak potensial dan aktual TI pada kinerja perusahaan. Dalam konteks riset Porter, Ives dan Learmonth (1984) dalam Rivard (2006) memfokuskan pada penggunaan TI untuk memperkuat hubungan antara perusahaan dan konsumen. Mereka mengusulkan untuk menggunakan siklus hidup sumber daya konsumen sebagai alat untuk menentukan bagaimana perusahaan dapat menggunakan TI untuk membedakan perusahaan dari pesaingnya dengan menjadi produsen berbiaya rendah atau mengidentifikasi market niche. Peneliti menggunakan berbagai contoh perusahaan yang menggunakan TI untuk mendukung satu atau beberapa kegiatan siklus hidup konsumen, karena hal tersebut akan meningkatkan kekuatan hubungan mereka dengan konsumen. Melengkapi kerangka kekuatan bersaing dengan konsep value chain yang diperkenalkan oleh Porter (1985), Porter dan Millar (1985) menunjukkan bagaimana TI dapat mengubah persaingan dengan mengubah struktur industri, menciptakan keunggulan bersaing dengan memberikan cara baru kepada perusahaan untuk mengungguli pesaingnya dan bahkan menciptakan peluang untuk memulai bisnis baru. Dalam studi kasus dari empat perusahaan, Levy et al. (1999) menunjukkan bagaimana rantai nilai Porter dan kerangka lima kekuatan adalah hal yang berharga dalam analisis proses bisnis dan penggerak kompetitif untuk perusahaan kecil-menengah. Mereka menyarankan bahwa analisis rantai nilai mendorong untuk mengidentifikasi kegiatan yang mengkontribusi secara langsung profitabilitas, sementara model lima kekuatan mendorong perusahaan kecil menengah untuk melihat di luar batas operasional mereka. Dalam studi hubungan antara tujuan yang ditetapkan perusahaan untuk TI, praktek dan persepsi eksekutif terhadap nilai TI, Tallon et al. dalam Rivard et al. (2006) berdasarkan pada pendapat Porter (1996) dimana perusahaan secara berbeda memfokuskan pada dua tujuan utama, yaitu efektivitas operasional dan positioning strategis.

Menerjemahkan perbedaan ini kedalam tujuan yang sesuai dengan TI, mereka mengidentifikasi empat jenis tujuan korporat bagi TI: (1) Fokus operasional yang berjuang untuk efisiensi dan efektivitas. (2) Fokus pasar yang menerjemahkan ke dalam TI, ditujukan pada perluasan pasar dalam menjangkau perubahan industri dan praktek pasar. (3) Fokus ganda, yang merupakan kombinasi fokus dan pasar operasional. (4) Unfocused, dimana TI bukan hal kritis untuk berbagai aspek perusahaan. Dari analisis sampel 304 manajer bisnis, mereka menemukan bahwa eksekutif dalam perusahaan yang lebih fokus pada tujuan TI memahami tingkatan nilai bisnis TI yang lebih tinggi dan tingkatan keterpaduan strategik TI. Sebaliknya, tingkat yang lebih tinggi keterpaduan strategik yang dipersepsikan berhubungan dengan tingkat yang lebih tinggi dari nilai bisnis yang dipersepsikan (Rivard et al., 2006).

\section{Resource-Based View (RBV)}

Pandangan berbasis sumber daya perusahaan berasal dari studi Penrose (1959), dimana perusahaan digambarkan sebagai serangkaian sumber daya. Penrose menganggap bahwa pertumbuhan perusahaan difasilitasi dan dibatasi oleh pencarian manajemen untuk penggunaan sumber daya terbaik yang tersedia. Barney (1991) memberikan deskripsi yang tepat dan formal dari perspektif ini. Sumber daya termasuk aset, kapabilitas, proses, atribut, pengetahuan dan know-how yang dimiliki perusahaan dan yang dapat digunakan untuk memformulasikan dan mengimplementasikan strategi bersaing. RBV mendasarkan pada dua pernyataan fundamental, yaitu resource heterogeneity (sumber daya dan kapabilitas yang dimiliki perusahaan bisa berbeda) dan resource immobility (perbedaan ini mungkin bisa selamanya) (Mata, Fuerst dan Barney, 1995). Jika sumber daya yang dimiliki oleh perusahaan 
juga dimiliki oleh beberapa pesaingnya (no heterogeneity) sumber daya ini tidak dapat mengkontribusi keunggulan bersaing. Heterogeneity merupakan kondisi yang diperlukan untuk memperoleh paling tidak keunggulan bersaing yang sementara. Resource immobility merupakan kondisi yang diperlukan untuk keunggulan bersaing yang lestari, karena pesaing akan menghadapi keunggulan biaya dalam perolehan, pengembangan dan penggunaan dibandingkan perusahaan yang sudah memilikinya (Rivard et al., 2006).

\section{Perspective of Complementary}

Sementara kedua strategy as positioning perspective dan RBV dari perusahaan telah melayani sebagai dasar teoritis untuk riset hubungan antara TI dan nilai bisnis, dua aliran riset telah berkembang secara independen satu dari yang lain. Peneliti telah menjelaskannya sebagai pandangan bersaing (Duhan et al., 2001). Dalam riset strategi, bagaimanapun beberapa peneliti telah mengusulkan bahwa dua perspektif adalah saling melengkapi bukan berseberangan/berlawanan. Untuk mengilustrasikan perspektif saling melengkapi, beberapa peneliti menyarankan bahwa setiap perspektif meliputi satu komponen kerangka SWOT, dengan perspektif market driven menyediakan analisis yang berhubungan dengan peluang dan ancaman dan RBV berhubungan dengan kekuatan dan kelemahan (Spanos dan Lioukas, 2001). Spanos dan Lioukas (2001) dalam Rivard et al., (2006) mengusulkan gabungan model sehingga "untuk mengidentifikasi dampak relatif terhadap industri vs faktor spesifik perusahaan pada kinerja perusahaan”.

\section{IT Support}

Untuk tujuan studinya, Rivard et al., (2006) mengintegrasikan dua model yang diperkenalkan oleh Spanos dan Lioukas (2001) serta model yang diadopsi dari Henderson dan Venkatraman (1999). Model yang diadopsi dari Spanos dan Lioukas (2001) adalah model terintegrasi - resource-based view dan competitive strategy yang terdiri dari empat variabel: Strategy (innovative differentiation, marketing differentiation dan low cost), Firm Assets (organizational, marketing dan technical). Industry Forces (barriers to entry, power over suppliers, power over buyers, intensity to competition, threat of substitutes), Market Performance dan Profitability. Sedangkan model yang diadopsi dari Henderson dan Venkatraman (1999) adalah model strategic alignment dari dua perspektif - terdiri dari empat variabel : Business Strategy (competitive strategy perspective), IT Strategy, Organizational Infrastructure dan Processess (resource-based perspective) ; IT Infrastructure and Procesess. Hubungan antara Business Strategy dan IT Strategy adalah Strategic Integration (IT support for strategy), sedangkan hubungan antara Organizational Infrastructure \& Processess dan IT Infrastructure \& Procesess adalah Operational Integration (IT support for firm assets). Baik hubungan antara Business Strategy dan Organizational Infrastructure \& Processess maupun hubungan antara IT Strategy dan IT Infrastructure \& Process adalah strategic fit.

Model riset yang dikembangkan dari dua model yang diadopsi kemudian dikembangkan dengan mengintegrasikan kontribusi TI pada kinerja perusahaan. Model tersebut terdiri dari lima variabel yaitu : Industry Forces (barriers to entry, power over suppliers, power over buyers, intensity to competition, threat of substitutes); IT Support for Strategy (IT support for innovative differentiation, marketing differentiation dan low cost); IT Support for Firm Assets (IT support for organizational, marketing dan technical competencies); Market Performance dan Profitability.

\section{IT Capabilities}

Awal studi nilai bisnis TI menguji dampak investasi TI pada kinerja organisatoris, terutama pada tingkat perusahaan (Melville, Kraemer dan Gurbaxani dalam Kim et al., 2011). Banyak dari mereka mendasarkan pada pendekatan fungsi produksi (black box approach), dimana spesifikasi matematika dirumuskan berdasarkan pada teori mikroekonomi dan memanfaatkan hubungan input produksi (seperti tenaga kerja, TI, modal lain) dan output (kualitas dan kuantitas) dimana secara 
langsung (Brynjolfsson dan Hitt, 1996). Bagaimanapun paradigma riset didasarkan pada ide sederhana di mana TI menyediakan alat yang diperlukan untuk mengubah input menjadi output secara efektif (Orlikowski dan Iacono, 2001). Awal studi yang mendasarkan pada pendekatan black-box kurang konsisten dalam menjelaskan hubungan antara investasi TI dan kinerja organisatoris, mereka berangkat dari kontroversi paradox produktivitas TI (Brynjolfsson, 1993 dalam Kim et al., 2011).

Untuk menghadapi masalah paradox produktivitas, argumen telah dibuat bahwa riset pada nilai bisnis TI seharusnya mengkaji dampak TI pada proses bisnis (Ray, Barney dan Muhanna, 2005 dalam Kim et al., 2011). Pendukung menyatakan bahwa hal ini proses (cara lebih baik melakukan sesuatu) bukannya produk dimana TI membuat dampak yang benar (Mcafee dan Brynjolfsson, 2008). Tentu saja, mendasarkan pada pendekatan black-box berarti kehilangan kekuatan statistik dalam menentukan hubungan yang bermanfaat antara investasi TI dan kinerja organisasi karena jarak yang besar (kesenjangan temporal) antara mereka (Barua Kriebel dan Mukhopadhyay, 1995). Studi didasarkan pada model proses telah menunjukkan hasil yang lebih konsisten dan jelas (Ravichandran dan Lertwongsatien, 2005).

Saat ini, peneliti telah menggantungkan terutama pada RBV sebagai kerangka teoritis utama untuk memahami hubungan antara TI dan nilai bisnisnya. RBV menyatakan bahwa keunggulan bersaing muncul dari kombinasi unik sumber daya yang secara ekonomis bernilai, langka dan sulit untuk ditiru (Barney, 1991; Grant, 1991). Sumber daya ini secara heterogen didistribusikan lintas perusahaan dan sifat bawaan mereka seperti path dependency, embeddedness dan causal ambiguity membuat mereka batu loncatan bagi keunggulan bersaing (Barney, 1991). Literatur kapabilitas TI mengenali bahwa kompetensi dalam memobilisasi dan menyebarkan sumber daya berbasis TI merupakan sumber keunggulan bersaing dan membedakan kinerja perusahaan (Bharadwaj, 2000; Piccoli dan Ives, 2005; Ha dan Jeong, 2010). Studi saat ini tentang kapabilitas TI dilakukan pada basis RBV mengambil langsung (seperti Bhatt \& Grover, 2005; Powell \& dent-Micallef, 1997) dan tidak langsung (seperti Pavlou \& Elsawy, 2006; Tippins \& Sohi, 2003) memandang pemahaman hubungan antara kapabilitas TI dan kinerja perusahaan. Studi yang didasarkan pada dua paradigma riset umumnya melaporkan hubungan positif antara kapabilitas TI dan kinerja perusahaan.

Sebagaimana ditentukan, Process-Oriented Dynamic Capabilities (PDC) menggambarkan kapasitas perusahaan untuk mengubah proses organisatoris untuk mencapai integrasi yang lebih baik, pengurangan biaya, dan intelijen bisnis. Meningkatnya PDC, seharusnya meningkatkan efektivitas proses operasional perusahaan dengan mengijinkan akuisisi dan asimilasi pengetahuan internal dan eksternal, konfigurasi/rekonfigurasi basis sumber daya dan deployment/redeployment sumber daya dipadukan dengan visi korporat perusahaan (Liao, Kickul dan Ma, 2009). Perusahaan dengan PDC yang sangat baik diharapkan memperbaiki proses operasional yang tidak efektif menjadi lebih baik, lebih cepat dan lebih murah dibandingkan pesaing dan mengubahnya ke dalam proses responsif terhadap perubahan lingkungan bisnis (Butler \& Murphy, 2008; Eisenhardt \& Martin, 2000). Perusahaan tersebut dapat mengungguli pesaing dengan lebih bereaksi secara efektif untuk mengubah lingkungan melalui peningkatan komunikasi, koordinasi dan sharing informasi (Tippins \& Sohi, 2003). PDC juga dapat menghasilkan pembuatan keputusan dengan tepat dan akurat (Davenport \& Short, 1990; Eisenhardt \& Martin, 2000; Sher \& Lee, 2004). PDC yang sangat baik akan menimbulkan kinerja perusahaan lebih baik dan memberikan perusahaan keunggulan bersaing (Pavlou \& El-Sawy, 2006; Rothaermel \& Hess, 2007; Zollo \& Winter, 2002 dalam Kim et al., 2011).

\section{Organizational Performance}

Beberapa studi pada perusahaan skala besar, telah mencatat interaksi atribut lingkungan industri dengan strategi, kompetensi yang berbeda dan struktur perusahan yang berpengaruh pada kinerja (Hambrick, 1983a; Hitt dan Ireland, 1985 dalam Pelham, 1999). Ada karakteristik multidimensi terhadap kinerja organisasi (Pelham, 1999). Sebagai contoh: marketing/sales effectiveness (relative product quality, new product success and customer retention), growth/share 
(level of sales revenue, sales growth and target market share) dan profitability (return on equity, return on investment and gross profit margin). Dalam paper ini pengukuran kinerja organisasional akan menggunakan growth dan profitability.

\section{SIMPULAN}

Paper ini membahas tentang kerangka konseptual yang mengkaji hubungan Teknologi Informasi (TI) dan Strategi Kompetitif serta dampaknya terhadap Kinerja Organisatoris. Perlu dilakukan uji empirik terhadap model yang diusulkan dengan tujuan untuk menemukan hasil yang diharapkan.

\section{DAFTAR PUSTAKA}

Barney J. 1991. Firm resources and sustained competitive advantage. Journal of Management. 17, 99120.

Eisenhardt, K. M., Martin, M. (2000). Dynamic capabilities: What are they? Strategic Management Journal, 21(10), 1105-1121

Huang, Derrick, C., Hu, Qing. (2007). Achieving IT-Business Strategic Alignment via EnterpriseWide Implementation of Balanced Scorecards. Information Systems Management; Spring 2007, 24:173

Kim, Gimun, Shin, Bongsik, Kim, Kyung Kyu; Lee, Ho Geun. (2010). IT Capabilities, ProcessOriented Dynamic Capabilities, and Firm Financial Performance. Journal of the Association for Information Sytem, 12(7), 487-517.

Miles, R. E., Snow, C. C. (1978). Organizational strategy, structure, and process. New York: McGraw-Hill.

Pelham, A. M. (1999). Influence of Environment, strategy, and market orientation on performance in small manufacturing firms. Journal of Business Research, 45, 33-46.

Penrose, E. T. (2009). The Theory of Growth of the Firm. Oxford University Press Inc., New York. Fourth edition.

Porter, M. E. (1981). The contribution of Industrial Organization ro Strategic Management. Academy of Management Review ; Vol. 6, No. 4, 609-620.

(1980). Competitive Strategy. Free Press: NewYork.

. (1991). Towards A Dynamic Theory Of Strategy. Strategic Management Journal; 12, 95.

Rivard, S., Raymond, L., Verreault, D. (2006). Resource-based View \& Competitive Strategy: An Integrated Model of the Contribution of Information Technology to Firm Performance. Journal of Strategic Management Systems. 15, 29-50. 
Teece D J, Piano G, Shuen A (1997). Dynamic capabilities and strategic management. Strategic Management Journal, 18(7), 509-533 (2009). Dynamic capabilities and strategic management. Oxford University Press. First edition.

Tian, J., Wang, K., Chen, Y., Johansson, B. (2009). From IT Deployment Capabilities to Competitive Advantage: An Exploratory Study in China. Information System Front. 